\title{
PENGARUH MODEL PEMBELAJARAN PENDIDIKAN MATEMATIKA REALISTIK (PMR) TERHADAP KEMANDIRIAN BELAJAR SISWA
}

\author{
Michael Christian Simanullang ${ }^{1}$
}

\begin{abstract}
ABSTRAK
Penelitian ini bertujuan untuk meganalisis pengaruh model pembelajaran Pendidikan Matematika Realistik (PMR) terhadap kemandirian belajar siswa. Penelitian ini merupakan penelitian quasi eksperimen dengan desain pretes-postes kontrol. Instrumen yang digunakan dalam penelitian ini adalah: (1) lembar validasi dan (2) angket kemandirian belajar siswa. Hasil dari penelitian ini adalah: (1) skor kemandirian belajar siswa yang dibelajarkan dengan model pembelajaran PMR berada pada kategori baik; (2) terdapat perbedaan signifikan skor kemandirian belajar siswa yang dibelajarkan dengan model pembelajaran PMR dengan pembelajaran langsung; (3) skor kemandirian belajar siswa yang dibelajarkan dengan model pembelajaran PMR lebih baik daripada skor kemandirian belajar siswa yang dibelajarkan dengan pembelajaran langsung; dan (4) penerapan model pembelajaran PMR dapat meningkatkan kemandirian belajar siswa.
\end{abstract}

Kata Kunci: quasi eksperimen, model pembelajaran PMR, kemandirian belajar

\section{PENDAHULUAN}

Tujuan pembelajaran di sekolah berdasarkan kurikulum Indonesia (Kurikulum 2013) adalah untuk mempersiapkan manusia Indonesia agar memiliki kemampuan hidup sebagai pribadi yang beriman dan produktif, kreatif, inovatif serta mampu berkontribusi pada kehidupan bermasyarakat, berbangsa dan bernegara. Khususnya dalam pembelajaran matematika, bersumber dari Programme for International Student Assessment (PISA) diuraikan bahwa proses matematis yang harus dimiliki oleh siswa mencakup: memformulasikan situasi secara matematis; menggunakan fakta, konsep, prosedur dan penalaran matematis; dan menginterpretasikan, menerapkan dan mengevaluasi hasil (OECD, 2016). Trends In International Mathematics And Science Study (TIMSS) yang di dalamnya diuraikan bahwa ranah kognitif matematik yang harus dimilki siswa terdiri dari tiga aspek, yaitu: 1) mengetahui (knowing) yang mencakup fakta, konsep dan prosedur yang harus diketahui oleh siswa; 2) menerapkan (applying) yang difokuskan pada kemampuan siswa untuk menerapkan ilmu pengetahuan dan pemahaman konseptual untuk menyelesaikan masalah atau menjawab pertanyaan; dan 3) penalaran (reasoning) pada masalah yang tidak rutin, situasi yang unfamiliar, konteks yang kompleks, dan masalah - masalah dengan banyak tahap (Mullis dan Martin, 2013). National Council of Teachers of Mathematics (NCTM) menetapkan lima standar proses dalam pembelajaran matematika, yaitu pemecahan masalah, penalaran, komunikasi, representasi dan koneksi (Carpenter dan Gorg, 2000).

Fakta yang diperoleh dari salah satu SMP di kota Medan menunjukkan bahwa guru masih belum menggunakan model pembelajaran yang berlandaskan pada filosopi konstruktivisme sosial. Guru memberikan

${ }^{1}$ Michael Christian Simanullang

Program Studi Pendidikan Matematika, Universitas Negeri Medan,

Medan, 20221, Indonesia

E-mail: michaelsimanullang@unimed.ac.id materi pembelajaran dalam bentuk jadi, memberikan soal latihan dan tugas rumah. Pembelajaran yang demikian memberi petunjuk bahwa tidak terdapat peran aktif siswa dalam mengkonstuksi pengetahuan matematis formal. Siswa dibiasakan untuk menerima informasi baru tanpa mengaitkannya dengan informasi yang telah ia miliki sebelumnya. Materi pembelajaran yang disajikan pada buku (buku yang sama dipergunakan oleh guru dan siswa) didahului dengan situasi nyata yang belum dialami siswa dan tidak terdapat suatu konstruksi pengetahuan matematis formal di dalamnya. Akibatnya, siswa memiliki minat yang rendah dalam pembelajaran matematika. Guru tidak menggunakan LKS dalam pembelajaran, melainkan menggunakan buku soal. Buku soal tersebut berisikan soal - soal yang sebagian besar tidak merupakan masalah nyata (authentic task). Sedemikian sehingga, ketika siswa dihadapkan pada masalah masalah nyata (soal cerita yang dekat dengan siswa), siswa mengalami kesulitan dalam melakukan pemecahan masalah. Soal - soal di dalam buku itu sebagian besar merupakan soal - soal rutin yang terstruktur dengan baik (well-structured). Soal - soal yang seharusnya diterapkan adalah soal terbuka atau open ended, yang sifatnya tidak tersruktur dengan baik (ill-structured).

Penelitian menunjukkan bahwa keterampilan dan kemampuan siswa tidak secara utuh menjelaskan keberhasilan siswa, dimana terdapat faktor lain seperti kemandirian belajar dan motivasi yang mempengaruhinya (Schunk \& Zimmerman, 2012; Vrieling, et al., 2012). Hasil penelitian pendahuluan dengan memberikan angket kemandirian belajar kepada siswa pada kelas uji coba, menunjukkan bahwa kemandirian belajar siswa masih tergolong kurang. Fakta di lapangan menunjukkan bahwa tak jarang dijumpai siswa meninggalkan buku pelajarannya di sekolah. Siswa menyelesaikan tugas rumah di pagi hari sebelum pembelajaran dimulai. Siswa sering menyelesaikan tugas rumah yang diberikan guru dengan mencontek tugas rumah temannya. Akibatnya, 
ketika guru meminta siswa untuk menyelesaikan tugas rumah tersebut di depan kelas, ia tidak mampu melakukannya. Berdasarkan pada uraian tersebut dapat disimpulkan bahwa siswa tidak memiliki kemandirian belajar yang baik.

Situasi pembelajaran yang demikian harus diperbaiki, karena akan sulit bahkan tidak mungkin untuk mewujudnyatakan tujuan pembelajaran dalam kurikulum Indonesia, maupun tuntutan standard proses (ranah kognitif) pembelajaran matematika yang harus dimiliki siswa secara global. Pembelajaran matematika seharusnya memfasilitasi siswa untuk mengembangkan, mengkonstruksi maupun membentuk konsep, makna, proses dan nilai - nilai (Bishop, 1991). Pembelajaran yang demikian adalah pembelajaran yang berorientasi pada siswa (student oriented) yang memandang siswa memiliki potensi. Sejalan dengan uraian di atas, Treffers, de Moor dan Feijs menyatakan bahwa ada tiga pilar proses pembelajaran matematika dalam membangun pola pikir matematis, yaitu pembelajaran yang bersifat konstruktif, interaktif dan reflektif (Hasratuddin, 2017). Salah satu pendekatan pembelajaran yang sesuai dengan ketiga pilar proses pembelajaran tersebut adalah pendekatan matematika realistik (PMR). Pendekatan pembelajaran PMR dapat dijadikan sebagai alternatif untuk menciptakan sistem pendidikan yang demokratis dan berkarakter (Hasratuddin, 2017). Pembelajaran yang demikian menjadikan siswa sebagai subjek belajar yang harus berperan aktif dalam konstruksi pengetahuan matematis formal, yaitu secara dominan dalam proses penemuan fakta, konsep, operasi dan prinsip matematis dengan bersumber dari dunia nyata. Guru harus memandang siswa bukanlah sebagai wadah kosong yang siap untuk menerima pengetahuan matematis formal dalam bentuk jadi (ready - made). Guru harus memfasilitasi lingkungan belajar siswa di dalam kelas dengan tepat, yang mengijinkan siswa untuk mengkonstruksi pengetahuan matematis formal. Siswa memiliki potensi bukanlah berarti bahwa siswa dapat melakukan proses konstruksi tersebut dengan terlepas dari peran guru. Guru harus memandu proses konstruksi tersebut, sedemikian sehingga siswa dengan tuntunan guru dapat menemukan kembali pengetahuan matematis formal. Memandu proses konstruksi bukanlah berarti mendiktekan siswa dengan serangkaian perintah, melainkan menyelidiki proses berpikir siswa yang dengan itu guru mampu memberikan scaffolding yang tepat kepada siswa dalam proses konstruksi yang ia lakukan. Pendekatan PMR tersebut dapat dijadikan sebagai alternatif untuk meningkatkan kemandirian belajar siswa. Artinya, tujuan dari peelitian ini adalah untuk mengetahui pengaruh pendekatan PMR terhadap kemandirian belajar siswa.

\section{KAJIAN TEORITIS}

Landaan filisofis dari PMR adalah sesuai dengan gagasan dari Freudenthal yang memandang matematika sebagai aktivitas manusia (Freudenthal, 1973, 1991; Goffree, 1993; Treffers,1993; Gravemeijer, 1994; de Moor, 1994; de Lange, 1996). Gravemeijer (1994) menyatakan bahwa terdapat tiga prinsip kunci dalam PMR, yaitu: (1) guided reinvention/ progressive mathematizing (guided discovery/ mathematizing progressive); (2) didactical phenomenology; dan (3) self-developed models. Berdasarkan pada ketiga prinsip tersebut, pendekatan PMR terdiri dari lima karakterisitik, yaitu: (1) konstruksi (constructing) dan konkretisasi (concretizing); (2) level and models; (3) refleksi (reflection) dan penilaian khusus (special assessment); (4) konteks sosial (social context) dan interaksi (interaction) serta (5) strukturisasi (structuring) dan keterkaitan (intertwining) (Treffers, 1987; de Lange, 1987; Streefland, 1991; dan Gravemeijer, 1994).

Pendekatan PMR tersebut diterapkan untuk meningkatkan kemandirian belajar siswa. Indikator yang digunakan untuk mengukur kemandirian belajar yaitu: 1) inisiatif belajar, 2) mendiagnosa kebutuhan belajar, 3) menetapkan target dan tujuan belajar, 4) memonitor, mengatur dan mengontrol kemajuan belajar, 5) memandang kesulitan sebagai tantangan, 6) memanfaatkan dan mencari sumber yang relevan, 7) memilih dan menerapkan strategi belajar, 8) mengevaluasi proses dan hasil belajar dan 9) memiliki self -concept atau konsep diri (Zimmerman, 2002; Schunk, 2005; Eliserio, 2012; Cazan, 2012).

\section{METODE PENELITIAN}

Jenis penelitian adalah quasi eksperimen dengan desain pretest-postest kontrol. Pengelompokan subjek penelitian dilakukan secara acak, kelompok eksprimen diberi perlakuan pembelajaran dengan pendekatan matematika realistik $\left(X_{1}\right)$, dan kelompok kontrol diberi perlakuan pendekatan biasa $\left(X_{2}\right)$, sebelum dan sesudah perlakuan diberi pretes dan postes $(\mathrm{O})$.

$$
\begin{array}{lll}
\mathrm{O} & X_{1} & \mathrm{O} \\
\mathrm{O} & X_{2} & \mathrm{O}
\end{array}
$$

Subjek penelitian adalah siswa SMP di Kota Medan, yang terdiri dari 46 orang siswa pada kelas eksperimen dan 48 siswa pada kelas kontrol. Instrument penelitian menggunakan angket kemandirian belajar yang terdiri dari 30 pernyataan. Analisis data dilakukan dengan menggunakan teknik deskriptif kualitatif dan uji t.

\section{HASIL PENELITIAN}

\section{A. Validitas Perangkat Pembelajaran}

Kegiatan yang dilakuakan adalah meminta ahli dan praktisi untuk menilai validitas perangkat pembelajaran yang dikembangkan berdasarkan aspek penilaian yang ditetapkan. Hasil validasi dari ahli dan praktisi tersebut disajikan pada tabel 1 .

Tabel 1.Rerata Total Validitas Perangkat Pembelajaran

\begin{tabular}{clcccc}
\hline No. & $\begin{array}{c}\text { Aspek yang } \\
\text { Dinilai }\end{array}$ & RPP & BG & BS & LKS \\
\hline 1. & Format & 4,60 & 4,83 & 4,83 & 4,57 \\
\hline 2. & Isi & 4,73 & 4,60 & 4,66 & 4,51 \\
\hline 3. & Bahasa & 4,70 & 4,55 & 4,63 & 4,43 \\
\hline 4. & Ilustrasi & - & 4,60 & 4,67 & - \\
\hline & Rerata Total & $\mathbf{4 , 6 8}$ & $\mathbf{4 , 6 5}$ & $\mathbf{4 , 7 0}$ & $\mathbf{4 , 5 0}$ \\
\hline
\end{tabular}


Nilai rerata total validitas perangkat pembelajaran tersebut selanjutnya dirujuk kepada kriteria penentuan tingkat validitas perangkat pembelajaran, dan disimpulkan bahwa validitas perangkat pembelajaran berada pada kriteria valid.

B. Validitas dan Reliabilitas Angket Kemandirian Belajar (AKB)

Kegiatan yang dilakukan adalah meminta ahli dan praktisi untuk menilai validitas perangkat pembelajaran yang dikembangkan berdasarkan aspek penilaian yang ditetapkan. Hasil validasi dari ahli dan praktisi tersebut, disajikan pada tabel 2 .

Tabel 2. Validitas AKB

\begin{tabular}{clc}
\hline No. & $\begin{array}{c}\text { Aspek } \\
\text { yang } \\
\text { Dinilai }\end{array}$ & AKB \\
\hline 1. & $\begin{array}{l}\text { Validitas } \\
\text { Isi }\end{array}$ & Valid \\
\hline 2. & $\begin{array}{l}\text { Bahasa } \\
\text { dan } \\
\text { Penulisan }\end{array}$ & $\begin{array}{c}\text { Minimal } \\
\text { Dapat } \\
\text { Dipahami }\end{array}$ \\
\hline
\end{tabular}

Kegiatan pra-uji coba lapangan juga dilakukan pada 48 siswa kelas VII 7 (bukan subjek penelitian) untuk mengukur validitas statistik angket kemandirian belajar. Penentuan validitas setiap pernyataan adalah dengan menggunakan rumus korelasi product moment. Berdasarkan hasil olah data, disimpulkan bahwa semua pernyataan valid. Penentuan reliabilitas angket kemandirian belajar adalah dengan menggunakan rumus Alpha. Berdasarkan hasil olah data, disimpulkan bahwa angket kemandirian belajar memiliki derajad reliabilitas sangat tinggi (koefisien reliabilitas $\alpha$ sebesar 0,820 ).

\section{Kemandirian Belajar Siswa}

Rerata skor awal dan akhir kemandirian belajar siswa pada kelas eksperimen dan kontrol disajikan pada tabel 3. Rerata skor awal kemandirian belajar siswa pada kelas eksperimen dan kontrol jika dirujuk pada kriteria yang ditetapkan, maka masing - masing berada pada kriteria cukup.

Tabel 3. Rerata Skor Kemandirian Belajar Siswa pada Kelas Eksperimen dan Kontrol

\begin{tabular}{lcc}
\hline \multirow{2}{*}{ Kelas } & \multicolumn{2}{c}{ Kemandirian Belajar } \\
\cline { 2 - 3 } & Awal & Akhir \\
\hline Eksperimen & 69,24 & 81,88 \\
\hline Kontrol & 69,08 & 66,82 \\
\hline
\end{tabular}

Berdasarkan hasil uji normalitas yang dilakukan (lihat tabel 4.), maka disimpulkan bahwa rerata skor awal kemandirian belajar siswa pada kedua kelas subjek penelitian adalah berdistribusi normal (sig. = $0,2000>0,05)$.

Tabel 4. Uji Normalitas

\begin{tabular}{|c|c|c|}
\hline & $\begin{array}{l}\text { Kolmogorov- } \\
\text { Smirnov }^{a}\end{array}$ & Shapiro-Wilk \\
\hline & Statistic df Sig. & Statistic df Sig. \\
\hline $\begin{array}{l}\text { Kemandirian } \\
\text { Belajar Awal }\end{array}$ & $.06894 .200^{*}$ & 252 \\
\hline
\end{tabular}

Berdasarkan hasil uji homogenitas yang dilakukan (lihat tabel 5.), maka disimpulkan bahwa rerata skor awal kemandirian belajar siswa pada kedua kelas subjek penelitian adalah homogen (sig. $=0,952>$ $0,05)$.

Tabel 5. Uji Homogenitas

\begin{tabular}{llrllll}
\hline & & $\begin{array}{c}\text { Levene } \\
\text { Statistic }\end{array}$ & $d f 1$ & $d f 2$ & Sig. \\
\hline $\begin{array}{l}\text { Kemandirian } \\
\text { Belajar } \\
\text { Awal }\end{array}$ & $\begin{array}{l}\text { Based on } \\
\text { Mean }\end{array}$ & .005 & 1 & 92 & .945 \\
\cline { 2 - 7 } & $\begin{array}{l}\text { Based on } \\
\text { Median }\end{array}$ & .005 & 1 & 92 & .945 \\
& $\begin{array}{l}\text { Based on } \\
\text { Median } \\
\text { and with } \\
\text { adjusted df }\end{array}$ & .005 & 1 & 91.984 & .945 \\
& $\begin{array}{l}\text { Based on } \\
\text { trimmed } \\
\text { mean }\end{array}$ & .004 & 1 & 92 & .952 \\
\hline
\end{tabular}

Berdasarkan hasil uji normalitas dan homogenitas tersebut, maka untuk mengetahui apakah terdapat perbedaan skor akhir kemandirian belajar siswa pada kelas eksperimen dan kontrol dilakukan dengan uji t.

Tabel 6. Independent Samples Test

\begin{tabular}{llccc}
\hline & \multicolumn{3}{c}{$\mathrm{t}$-test for } & Equality of Means \\
\hline & \multicolumn{1}{c}{$t$} & $d f$ & $\begin{array}{c}\text { Sig. } \\
(2- \\
\text { tailed })\end{array}$ \\
\hline $\begin{array}{l}\text { Kemandirian } \\
\text { Belajar } \\
\text { Akhir }\end{array}$ & $\begin{array}{l}\text { Equal } \\
\text { variances } \\
\text { assumed }\end{array}$ & 11.213 & 92 & .000 \\
\cline { 2 - 5 } & $\begin{array}{l}\text { Equal } \\
\text { variances } \\
\text { not } \\
\text { assumed }\end{array}$ & 11.305 & 82.509 & .000 \\
\hline
\end{tabular}

Berdasarkan hasil uji beda yang dilakukan (lihat tabel 6.), maka dapat disimpulkan bahwa terdapat perbedaan yang signifikan antara skor akhir kemandirian belajar siswa pada kelas eksperimen dengan kelas kontrol (sig. $=0.000<0,05$ ).

Berdasarkan rerata skor kemandirian belajar siswa dari kedua kelas tersebut, maka disimpulkan bahwa skor kemandirian belajar siswa kelas eksperimen yang dibelajarkan dengan model pembelajaran PMR lebih baik daripada skor kemandirian belajar siswa kelas kontrol yang dibelajarkan dengan pembelajaran langsung. Rerata skor kemandirian belajar siswa pada setiap indikatornya, disajikan pada tabel 7 .

Berdasarkan pada tabel 7. tersebut, dapat diketahui bahwa rerata skor indikator kedelapan kemandirian belajar siswa yaitu siswa memanfaatkan dan mencari sumber belajar yang relevan sebelum penerapan model pembelajaran PMR merupakan skor tertinggi jika dibandingkan dengan rerata skor indikator kemandirian belajar lainnya. Hasil yang berbeda setelah penerapan model pembelajaran PMR, dimana rerata skor indikator kelima kemandirian belajar siswa yaitu siswa memilih 
Vol. 13, No. 2, Desember 2020

dan menerapkan strategi belajar merupakan skor tertinggi jika dibandingkan dengan rerata skor indikator kemandirian belajar lainnya. Pencapaian rerata skor indikator pertama kemandirian belajar siswa yaitu siswa menunjukkan inisiatif dalam belajar matematika merupakan skor terendah jika dibandingkan dengan rerata skor indikator kemandirian belajar lainnya sebelum penerapan model pembelajaran PMR. Pencapaian rerata skor indikator kesembilan kemandirian belajar siswa yaitu siswa yakin tentang dirinya sendiri merupakan skor terendah jika dibandingkan dengan rerata skor indikator kemandirian belajar lainnya setelah penerapan model pembelajaran PMR. Berdasarkan pada pencapaian skor awal dan akhir tersebut, disimpulkan bahwa penerapan model pembelajaran PMR dapat meningkatkan setiap indikator kemandirian belajar siswa kelas VII 12, kecuali indikator kedelapan yaitu siswa memanfaatkan dan mencari sumber belajar yang relevan. Rerata skor awal dan akhir untuk setiap indikator kemandirian belajar siswa kelas VII 12 disajikan pada diagram 1.

Tabel 7. Rerata Skor Setiap Indikator Kemandirian Belajar Siswa pada Kelas Eksperimen

\begin{tabular}{|c|c|c|}
\hline \multirow{2}{*}{ Indikator Kemandirian Belajar } & \multicolumn{2}{|c|}{ Rerata Skor } \\
\hline & Awal & Akhir \\
\hline $\begin{array}{l}\text { Siswa menunjukkan inisiatif } \\
\text { dalam belajar matematika }\end{array}$ & 60,51 & 81,16 \\
\hline $\begin{array}{l}\text { Siswa mendiagnosa kebutuhan } \\
\text { dalam belajar matematika }\end{array}$ & 61,96 & 80,16 \\
\hline $\begin{array}{l}\text { Menetapkan target atau tujuan } \\
\text { belajar }\end{array}$ & 63,77 & 81,52 \\
\hline $\begin{array}{l}\text { Siswa memonitor, mengatur dan } \\
\text { mengontrol belajar }\end{array}$ & 63,04 & 81,79 \\
\hline $\begin{array}{l}\text { Siswa memilih dan menerapkan } \\
\text { strategi belajar }\end{array}$ & 80,43 & 85,87 \\
\hline $\begin{array}{l}\text { Siswa mengevaluasi proses dan } \\
\text { hasil belajar }\end{array}$ & 67,26 & 83,51 \\
\hline $\begin{array}{l}\text { Siswa memandang kesulitan } \\
\text { sebagai tantangan }\end{array}$ & 78,26 & 82,61 \\
\hline $\begin{array}{l}\text { Siswa memanfaatkan dan mencari } \\
\text { sumber belajar yang relevan }\end{array}$ & 84,06 & 81,52 \\
\hline $\begin{array}{l}\text { Siswa yakin tentang dirinya } \\
\text { sendiri }\end{array}$ & 67,53 & 80,03 \\
\hline Kemandirian Belajar & 69,65 & 82,02 \\
\hline $\begin{array}{lllllll}11 & 12 & 13 & 14 & 15 & 16 & 17 \\
\text { Indikator Kemandirian Belajar }\end{array}$ & I8 19 & -Awal \\
\hline
\end{tabular}

Diagram 1. Representasi Kemandirian Belajar Siswa pada Kelas Eksperimen

Keterangan:

I1 : Siswa menunjukkan inisiatif dalam belajar matematika
I2 : Siswa mendiagnosa kebutuhan dalam belajar matematika

I3 : Menetapkan target atau tujuan belajar

I4 : Siswa memonitor, mengatur dan mengontrol belajar

I5 : Siswa memilih dan menerapkan strategi belajar

I6 : Siswa mengevaluasi proses dan hasil belajar

I7 : Siswa dapat memandang kesulitan sebagai tantangan

I8 : Siswa memanfaatkan dan mencari sumber belajar yang relevan

I9 : Siswa yakin tentang dirinya sendiri

Peningkatan skor kemandirian belajar siswa kelas eksperimen secara klasikal dilakukan dengan menentukan nilai gain ternormalisasi rata - rata (average normalized gain). Nilai gain ternormalisasi rata - rata $(\langle g\rangle)$ tersebut ditentukan dengan menggunakan rumus (Hake, 2008: 498):

$$
\langle g\rangle=(\langle \% \text { post }\rangle-\langle \% \text { pre }\rangle) /(100-\langle \% \text { pre }\rangle) \text {, }
$$

dimana kurung sudut menunjukkan rerata klasikal, dan diperoleh $\langle g\rangle=0.41$. Nilai $\langle g\rangle$ sebesar 0.41 tersebut jika dirujuk terhadap interval penentuan klasifikasi nilai $\langle g\rangle$ yang ditetapkan, maka disimpulkan bahwa klasifikasi peningkatan skor kemandirian belajar siswa kelas eksperimen berada pada kriteria sedang.

\section{Proses Pembelajaran}

Tahapan pembelajaran dalam model PMR terdiri dari lima tahap. Tahap pertama, pengajuan tantangan kontekstual. Guru harus memastikan setiap siswa telah siap untuk menerima pembelajaran. Guru mengkondisikan dan memastikan setiap siswa yang berada pada kelompok belajar yang sama agar duduk berdekatan (bukan duduk berkelompok/melingkar). Khusus untuk pembelajaran pada pertemuan pertama, guru menyampaikan deskripsi singkat tentang: (1) model pembelajaran PMR dan (2) peran siswa maupun guru dalam proses pembelajaran. Guru membagikan buku siswa kepada setiap siswa. Guru mengingatkan keterkaitan materi pembelajaran bangun datar segiempat terhadap: (1) materi pembelajaran sebelumnya yang siswa telah alami, serta (2) dunia nyata siswa. Kegiatan guru selanjutnya adalah menyampaikan tujuan pembelajaran yang akan dicapai siswa, diikuti dengan pengajuan tantangan kontekstual kepada siswa secara klasikal. Tahap kedua, mengeksplorasi tantangan kontekstual. Guru memandu (memotivasi) siswa untuk menskema, merumuskan dan memvisualkan tantangan kontekstual secara individu. Siswa yang telah memiliki penyelesaian dari tantangan kontekstual akan membandingkan atau mendiskusikan penyelesaiannya tersebut dengan siswa - siswa lainnya di dalam kelompok belajarnya nantinya. Siswa yang belum mampu memberikan penyelesaian, diharapkan agar mendaftarkan (menuliskan) kesulitan - kesulitan yang ia alami dalam menemukan penyelesaian dari tantangan kontekstual. Reaksi guru demi menekan keadaan demikian adalah memandu siswa (memberi scaffolding) (baik secara klasikal maupun individu) dengan bentuk pertanyaan peniring, ilustrasi, atau masalah sederhana yang relevan (tentu saja yang siswa 


\section{PARADIKMA JURNAL PENDIDIKAN MATEMATIKA}

Vol. 13, No. 2, Desember 2020

telah alami). Urutan pertanyaan pengiring jika diberikan secara individu harus disesuaikan dengan proses berpikir siswa. Tahap ketiga, merefleksikan tantangan kontekstual. Guru mengorganisasikan siswa untuk belajar berkelompok, artinya siswa yang sekelompok yang telah duduk berdekatan selanjutnya memposisikan dirinya agar duduk melingkar. Guru membagikan tiga exemplar lembar kerja siswa (LKS) kepada setiap kelompok belajar. Ketiga exemplar LKS tersebut harus diisi oleh setiap kelompok, dengan catatan bahwa satu exemplar akan dikumpul kepada guru sebagai laporan kerja kelompok; satu exemplar akan ditempel pada tempat yang disediakan (dinding ruangan kelas); dan satu exemplar lagi menjadi pertinggal untuk masing - masing kelompok belajar. Setiap siswa diharuskan untuk menuliskan hasil diskusi kelompoknya masing - masing pada buku catatannya. Guru memandu siswa untuk menggunakan LKS tersebut. Guru memotivasi siswa agar berperan aktif dalam setiap kelompok belajarnya (tidak bekerja secara individu), dimana setiap siswa dalam kelompok belajarnya masing - masing harus mendiskusikan penyelesaian atau kesulitan - kesulitan yang ia temukan pada tahap kedua sebelumnya. Guru memberikan scaffolding kepada setiap kelompok belajar (secara klasikal) untuk menghasilkan model/skema dari (model of) tantangan kontekstual. Scaffolding yang diberikan kepada setiap kelompok belajar dapat berupa scaffolding yang diberikan pada tahap kedua sebelumnya. Scaffolding tersebut harus disesuaikan dengan kebutuhan dari masing - masing kelompok belajar. Interaksi antar siswa tersebut memfasilitasi siswa untuk menyelidiki proses berpikir temannya yang lain. Urutan pengajuan pendapat antar siswa tidak berlangsug secara mekanistik, melainkan berlangsung secara spontan antara satu dan lainnya. Situasi pembelajaran yang demikian akan menuntun siswa untuk membuat model matematis (model for) untuk menyelesaikan tantangan kontekstual. Tahap keempat, berbagi penyelesaian (sharing) secara klasikal (formalisasi dan generalisasi). Guru memfasilitasi diskusi kelompok secara klasikal dengan memberi kesempatan kepada salah satu kelompok belajar (dilakukan secara bergiliran) mempresentasikan hasil diskusinya di depan kelas. Guru memandu semua kelompok belajar (melalui utusan kelompok) untuk menempelkan hasil diskusinya (LKS yang telah diselesaikan) pada tempat yang disediakan, yaitu dinding ruangan kelas. Guru membimbing siswa dalam kelompok belajar lainnya untuk: (1) mempersiapkan beberapa pertanyaan yang merupakan kesulitan yang mereka hadapi selama berdiskusi di dalam kelompok belajarnya masing - masing; (2) memeriksa dan membandingkan hasil diskusi kelompoknya masing masing dengan hasil diskusi kelompok penyaji. Guru selanjutnya memberi kesempatan kepada siswa dari kelompok yang lain untuk memberi tanggapan, atau mengajukan pertanyaan terhadap presentasi kelompok penyaji. Peran guru dalam menanggapi perbedaan pendapat antar siswa yang tidak memiliki kesepakatan bersama adalah dengan memberikan scaffolding, yang berupa pertanyaan pengiring, iluastrasi atau masalah - masalah sederhana lainnya yang relevan terhadap tantangan kontekstual yang diajukan. Siswa yang telah memiliki kesepakan dalam penyelesaian tantangan kontekstual yang diajukan, selanjutnya dipandu oleh guru untuk merumuskan (memformulasikan) dan menyimpulkan konsep dan prinsip matematis yang diharapkan dicapai oleh siswa. Tahap kelima, implementasi pengetahuan matematis formal. Guru mengkondisikan siswa untuk kembali ke bangkunya semula. Guru mengajukan tantangan kontekstual yang baru kepada siswa secara klasikal untuk diselesaikan secara indivudu, tanpa menggunakan buku siswa maupun perangkat pembelajaran lainnya yang relevan. Guru memotivasi setiap siswa secara klasikal untuk percaya kepada kemampuannya, menggunakan konsep dan prinsip matematis yang telah ditemukan pada tahap sebelumnya. Guru mengingatkan siswa - siswa yang telah menyelesaikan tantangan kontekstual yang baru tersebut agar memeriksa kembali hasil kerjanya. Guru kemudian mengumpulkan hasil kerja siswa pada waktu yang telah ditentukan. Guru dapat memberikan tugas rumah yang berkaitan dengan pengalaman belajar yang telah diterimanya secara klasikal. Guru mengingatkan siswa secara klasikal untuk (1) memantapkan pemahamannya terhadap materi pembelajaran berdasarkan pengalaman belajar yang telah diterimanya dan (2) mempersiapkan dirinya pada materi pembelajaran berikutnya, dengan membaca buku siswa atau sumber bacaan lainya.

\section{PEMBAHASAN}

Jenis penelitian ini adalah quasi eksperimen dengan desain pretest-postest kontrol. Tujuan penelitian ini adalah untuk mengetahui pengaruh model pembelajaran PMR terhadap kemandirian belajar siswa. Sintaks model PMR terdiri dari lima tahap, yaitu: (1) pengajuan tantangan kontekstual; (2) mengeksplorasi tantangan kontekstual; merefleksikan tantangan kontekstual; (4) berbagi penyelesaian (sharing) secara klasikal (formalisasi dan generalisasi); dan (5) implementasi pengetahuan matematis formal.

Sintaks model ini mengindikasikan bahwa pembelajaran yang dihasilkan merupakan pembelajaran yang berdasarkan pada paham konstruktivisme (Ernest, 1991; Glasersfeld, 1995; Bozkurt, 2017), yang menekan dominasi guru dalam pembelajaran. Terdapat pergeseran peran guru dalam model pembelajaran PMR ini jika dibandingkan dengan pembelajaran langsung. Berdasarkan pada komponen prinsip reaksi dan pengelolaan, guru tidak berperan sebagai sumber informasi yang memberikan konsep dan prinsip matematis dalam bentuk jadi kepada siswa, seperti yang berlangsung pada pembelajaran langsung. Guru menjembatani interaksi (van den Heuvel-Panhuizen, 2003; Hasratuddin, 2017) antar siswa (diskusi dalam kelompok belajarnya dan secara klasikal) maupun siswa dengan lingkungan belajarnya (secara individu/ berkelompok dengan perangkat pembelajaran yang digunakan). Guru tidak mendiktekan siswa dengan serangkaian perintah yang sifatnya mekanistik (Nelissen dan Tomic, 1993; Widjaja dan Heck, 2003; 
Vol. 13, No. 2, Desember 2020

Jupri dan Drijvers, 2016) dalam konstruksi pengetahuan matematis formal maupun memberikan penyelesaian atas tantangan kontekstual yang akan diselesaikan, melainkan berperan sebagai pemandu atau pemberi scaffolding (Surya and Syahputra, 2017) agar siswa mampu menemukan kembali konsep dan prinsip matematis ataupun menyelesaikan tantangan kontekstual yang diberikan. Guru justru harus memastikan mekanisme sintaks model pembelajaran PMR agar berlangsung sebagaimana seharusnya, tetapi berbeda halnya dengan interaksi antar siswa maupun siswa dengan lingkungan belajarnya harus berlangsung senatural mungkin. Artinya, siswa diberikan kesempatan oleh guru untuk menggunakan strategi kemandirian belajar mapun pengalaman belajarnya sebelumnya dalam proses kontsruksi yang berlangsung.

Peran siswa yang diwujudnyatakan dengan model pembelajaran PMR ini diawali dengan aktivitas eksplorasi (Budinski dan Milinkovic, 2017) terhadap tantangan kontekstual yang diterimanya secara individu menggunakan buku siswa dan dipandu oleh guru. Explorasi ini memfasilitasi siswa untuk menggunakan strategi kemandirian belajarnya, dimana siswa berusaha untuk mendaftarkan informasi yang diketahui dan menemukan hubungannya dengan hal yang ditanyakan dalam tantangan kontekstual; membuat model dari tantangan kontekstual dalam bentuk gambar, tabel, atau skema; maupun mencoba - coba kemungkinan kemungkinan yang berkaitan dengan penyelesaian dari tantangan kontekstual. Aktivitas eksplorasi ini tidak menutup kemungkinan bahwa siswa menemukan penyelesaian dari tantangan kontekstual. Walaupun demikian, hasil dari aktivitas eksplorasi ini adalah bahwa siswa seminimal mungkin dapat mendaftarkan kesulitan - kesulitan yang ia temukan dalam penyelesaian tantangan kontekstual atau konstruksi pengetahuan matematis formal. Eksplorasi ini berkontribusi kepada setiap siswa bahwa ia telah menemukan hal - hal yang harus ia diskusikan dalam kelompok belajarnya nantinya. Peran siswa selanjutnya adalah berdiskusi dalam kelompok belajarnya maupun secara klasikal. Hasil dari interaksi antar siswa dalam kelompok belajarnya masing - masing adalah suatu temuan yang berupa psoses penyelesaian tantangan kontekstual secara formal, yaitu pergeseran dari model of yang sifatnya informal menuju model for yang sifatnya formal (Ernest, 1991; Gravemeijer, 1994; Presmeg, 2003; van den Heuvel-Panhuizen and Drijvers, 2014). Proses penyelesaian tantangan kontekstual maupun penemuan pengetahuan matematis formal yang baru oleh setiap kelompok belajar mengindikasikan bahwa siswa memiliki cara yang berbeda - beda dalam mengimplementasikan pengetahuan matematis formal yang sebelumnya ia miliki. Guru dalam memberikan scaffolding kepada setiap kelompok belajar harus berdasarkan kebutuhannya (proses berpikir atau proses penyelesaian) masing - masing.

Model pembelajaran PMR ini memfalisitasi siswa untuk saling berkolaborasi, atau merupakan pembelajaran kooperatif. Pembelajaran kooperatif didasari oleh dua elemen kunci (Slavin, 2008, 2014;
Laal, et al., 2013; Gillies, 2014), yaitu tujuan kelompok (grup goal) dan pertanggungjawaban individu (individual accountability), bahwa setiap siswa dalam setiap kelompok belajar atau secara klasikal merupakan individu yang saling bergantung antara satu dan lainnya (didasari oleh potensi yang berbeda - beda) dan mengharuskan partisipasi dari setiap siswa dalam pembelajaran. Konsep kemandirian belajar dalam penelitian ini dihadirkan untuk memperjelas kedua elemen kunci tersebut.

Perangkat pembelajaran yang dihasilkan sebagai sistem pendukung dari model pembelajaran PMR dalam pelaksanaan pembelajaran pada materi pembelajaran bangun datar segiempat terdiri dari (1) RPP; (2) BG; (3) BS; (4) LKS; dan (5) AKB. Tingkat validitas perangkat pembelajaran yang dihasilkan termasuk dalam kategori valid. Tingkat penncapaian kemandirian belajar siswa secara klasikal berada pada kategori baik.

Penerapan model pembelajaran PMR ini dapat meningkatkan kemandirian belajar siswa pada kelas eksperimen. Hasil penelitian ini sejalan dengan penelitian sebelumnya yang relevan, bahwa pendekatan PMR merupakan alternatif untuk membangun dan meningkatkan sistem pendidikan yang demokratis (Hasratuddin, 2017). Pembelajaran yang demokratis tidak mengontrol siswa dalam keseluruhan proses pembelajaran, melainkan menghasruskan peran aktif siswa untuk: 1) berinisiatif dalam belajar, 2) mendiagnosa kebutuhan belajar, 3) menetapkan target dan tujuan belajar, 4) memonitor, mengatur dan mengontrol kemajuan belajar, 5) memandang kesulitan sebagai tantangan, 6) memanfaatkan dan mencari sumber yang relevan, 7) memilih dan menerapkan strategi belajar, 8) mengevaluasi proses dan hasil belajar dan 9) memiliki self -concept atau konsep diri yang baik, yang merupakan indikator dari kemandirian belajar.

Peningkatan kemandirian belajar siswa pada kelas eksperimen dapat dilihat dari peningkatan dari setiap indikatornya. Penerapan model pembelajaran PMR dapat meningkatkan setiap indikator kemandirian belajar siswa, kecuali indikator kedelapan yaitu siswa memanfaatkan dan mencari sumber belajar yang relevan. Indikator kedelapan kemandirian belajar tersebut tidak dapat ditingkatkan karena dalam penelitian pengembangan ini dihasilkan perangkat pembelajaran sebagai sistem pendukung dari model pembelajaran PMR. Artinya, perangkat pembelajaran yang dihasilkan adalah sumber belajar yang digunakan siswa untuk meningkatkan kemandirian belajarnya. Pemanfaatan sumber belajar lainnya, seperti media online melalui smartphone, tidak dapat dilaksanakan dalam penelitian ini karena merupakan peraturan sekolah (sebagai tempat penelitian) yang telah ditetapkan. Pemanfaatan sarana pembelajaran, seperti perpustakaan, tidak dapat dilaksanakan dalam proses pembelajaran karena keterbatasan waktu penelitian yang tersedia. Walaupun demikian, penerapan model pembelajaran PMR dalam penelitian ini dapat meningkatkan kemandirian belajar siswa secara klasikal. 
Indikator kemandirian belajar tersebut jika dikonfirmasi terhadap sintaks model pembelajaran PMR yang sedang dikembangkan ini, maka dapat diketahui bahwa:

- inisiatif belajar; mendiagnosa kebutuhan belajar; memandang kesulitan sebagai tantangan; memanfaatkan dan mencari sumber yang relevan; memilih dan menerapkan strategi belajar; dan memiliki self -concept atau konsep diri dapat dicapai khususnya pada tahap kedua model pembelajaran PMR, yaitu mengeksplorasi tantangan kontekstual.

* inisiatif belajar; mendiagnosa kebutuhan belajar; menetapkan target dan tujuan belajar; memonitor, mengatur dan mengontrol kemajuan belajar; memanfaatkan dan mencari sumber yang relevan; memilih dan menerapkan strategi belajar; mengevaluasi proses dan hasil belajar; dan memiliki self -concept atau konsep diri dapat dicapai khususnya pada tahap ketiga dan keempat model pembelajaran PMR, yaitu merefleksikan tantangan kontekstual dan berbagi penyelesaian (sharing) secara klasikal (formalisasi dan generalisasi).

- mendiagnosa kebutuhan belajar; menetapkan target dan tujuan belajar; memonitor, mengatur dan mengontrol kemajuan belajar; memandang kesulitan sebagai tantangan; memanfaatkan dan mencari sumber yang relevan; memilih dan menerapkan strategi belajar; mengevaluasi proses dan hasil belajar; dan memiliki self -concept atau konsep diri dapat dicapai khususnya pada tahap kelima model pembelajaran PMR, yaitu implementasi pengetahuan matematis formal.

\section{KESIMPULAN}

Berdasarkan hasil analisis data dan pembahasan dalam penelitian ini, dikemukakan beberapa simpulan sebagai berikut:

1. Skor kemandirian belajar siswa secara klasikal yang dibelajarkan dengan model pembelajaran Pendidikan Matematika Realistik (PMR) berada pada kategori baik

2. Terdapat perbedaan signifikan skor kemandirian belajar siswa yang dibelajarkan dengan model pembelajaran Pendidikan Matematika Realistik (PMR) dengan pembelajaran langsung.

3. Skor kemandirian belajar siswa yang dibelajarkan dengan model pembelajaran Pendidikan Matematika Realistik (PMR) lebih baik daripada skor kemandirian belajar siswa yang dibelajarkan dengan pembelajaran langsung.

4. Penerapan model pembelajaran Pendidikan Matematika Realistik (PMR) dapat meningkatkan kemandirian belajar siswa.

\section{UCAPAN TERIMA KASIH}

Penulis mengucapkan terima kasih kepada:

1. Ibu Dra. Tania Salim selaku Kepala SMP Sutomo 1 Medan.
2. Keluarga saya tercinta atas doa dan dukungan yang diberikan.

\section{REFERENSI}

Bishop, A. J. 1991. Mathematical Enculturation: A Cultural Perspektive on Mathematics Education. Dordrecht: Kluwer Academic Publishers.

Bozkurt, G. 2017. Social Constructivism: Does it Succeed in Reconciling Individual Cognition with Social Teaching and Learning Practices in Mathematics?. Journal of Education and Practice, 8(3).

Budinski, N. \& Milinkovic, D. 2017. Transition from Realistic to Real World Problems with The Use of Technology in Elementary Mathematical Education. Acta Didactica Napocensia, 10(1).

Carpenter, J. \& Gorg, S. 2000. Principles and Standards for School Mathematics. USA: NCTM, Inc.

Cazan, A. M. 2012. Assessing Self Regulated Learning: Qualitative vs Quantitative Research Methods. International Conference of Scientific Paper AFASES.

Eliserio, D. 2012. Self-Regulated Learning and Mathematics Achievement in a Fourth Grade Classroom. Master of Education Program Theses, 27.

Ernest, P. 1991. The Philosophy of Mathematics Education. Taylor \& Francis Group: Routledge Falmer.

Freudenthal, H. 1973. Mathematics as An Educational Task. Dordrecht-Holland: D. Reidel Publishing Company.

Freudenthal, H. 1991. Revisiting Mathematics Education. Dordrecht: Kluwer Academic Publishers.

Gillies, R. M. 2014. Cooperative Learning: Developments in Research. IJEP - International Journal of Educational Psychology, 3(2):125140.

Glasersfeld, E. von. 1995. Radical Constructivism: A Way of Knowing and Learning. London: Taylor \& Francis.

Goffree, F. 1993. HF: Working on Mathematics Education. Educational Studies in Mathematics, 25:21-49.

Gravemeijer, K. 1994. Developing Realistic Mathematics Education. Utrecht: Institute.

Hake, R. R. 2008. Design-Based Research in Physics Education: A Review. In A. E. Kelly, R. A. Lesh, \& J. Y. Baek. Handbook of Design Research Methods in Education: Innovations in Science, Technology, Engineering, and Mathematics Learning and Teaching (pp. 493-508). New York: Routledge, Taylor \& Francis.

Hasratuddin. 2017. Improving Critical Thinking and Emotional Intelligence Capabilities of Secondary School Students Through Realistic Mathematics Education Approach. International Journal of Innovation in Science and Mathematics, 5(1).

Heuvel-Panhuizen, M. van den. 2003. The Didactical Use of Models in Realistic Mathematics 
Education: An Example From a Longitudinal Trajectory on Percentage. Educational Studies in Mathematics, 54:9-35.

Heuvel-Panhuizen, M. van den \& Drijvers, P. 2014. Realistic Mathematics Education. In S. Lerman (Ed). 2014. Encyclopedia of Mathematics Education (pp. 521-525). Dordrecht: Springer Science+Business Media.

Jupri, A. \& Drijvers, P. 2016. Student Difficulties in Mathematizing Word Problems in Algebra. Eurasia Journal of Mathematics, Science \& Technology Education, 12(9):2481-2502.

Laal, M.; Geranpaye, L.; \& Daemi, M. 2013. Individual Accountability in Collaborative Learning. Procedia - Social and Behavioral Sciences, 93:286-289.

Lange, Jan de. 1987. Mathematics, Insight, and Meaning. The Netherlands, Utrecht: OW \& OC.

Lange, Jan de. 1996. Using and Applying Mathematics in Education. In A. J. Bishop; K. Clements; C. Keitel; J. Kilpatrick; \& C. Laborde (Eds). International Handbook of Mathematics Education (pp.49-97). The Netherlands: Kluwer Academic Publishers.

Moor, E. de. (1994). Geometry Instruction in the Netherlands - The Realistic Approach. In Streefland, Leen (Ed.). Realistic Mathematics Education in Primary School (pp.119-139). Freudenthal Institute: Utrecht.

Mullis, I. V. S. \& Martin, M. O. (Eds). 2013. TIMSS 2015 Assessment Frameworks. United States: International Association for the Evaluation of Educational Achievement (IEA).

Nelissen, J. \& Tonic, W. 1993. Learning and Thought Processes in Realistic Mathematics Instruction. Curriculum and Teaching, 8(1).

OECD. (2016). PISA 2015: Assessment and Analytical Framework: Science, Reading, Mathematic and Financial Literacy. Paris: PISA, OECD Publishing.

Presmeg, N. 2003. Creativity, Mathematizing, and Didactizing: Leen Streefland'swork Continues. Educational Studies in Mathematics, 54:127-137.

Schunk, D. H. \& Zimmerman, B. J. (Eds.). 2012. Motivation and Self-Regulated Learning: Theory, Research, and Applications. Routledge.

Schunk, D. H. 2005. Self-Regulated Learning: The educational legacy of Paul R. Pintrich. Educational Psychologist, 40:85-94.

Slavin, R. E. 2008. Cooperative Learning, Success for All, and Evidence-Based Reform in Education. Education \& Didactique, 2(2): 151-159.

Streefland, L. (1991). Fractions in Realistic Mathematics Education: A Paradigm of Developmental Research. Netherlands: Kluwer Academic Publisher.

Surya, E. \& Syahputra, E. 2017. Improving High Level Thinking Skills by Development of Learning PBL Approach on the Learning Mathematics for Senior High School Students. International Education Studies, 10(8).
Treffers, A. 1987. Three Dimensions: A Model of Goal and Theory Description in Mathematics Instruction - The Wiskobas Project. DordrechtHolland: D. Reidel Publishing Company.

Treffers, A. 1993. Wiskobas Freudenthal Realistic Mathematics Education. Educational Studies in Mathematics, 25:21-49.

Vrieling, E.; Bastiaens, T.; \& Stijnen, S. 2012. Consequences of Increased Self-Regulated Learning Opportunities on Student Teachers' Motivation and Use of Metacognitive Skills. Australian Journal of Teacher Education, 37(8).

Widjaja, Y. B. \& Heck, A. 2003. How a Realistic Mathematics Education Approach and Microcomputer - Based Laboratory Worked in Lessons on Graphing at an Indonesian Junior High School. Journal of Science and Mathematics Education in Southeast Asia, 26(2):1-51. 